\title{
Chapter 22 \\ The Marginalized and Poorest in Different Communities and Settings of Ethiopia
}

\author{
Tadesse Woldemariam Gole, Fite Getaneh Ilfata, Motuma Tafa, \\ and Aleka Aregachew
}

\begin{abstract}
This chapter describes how the extent of poverty and the causes and nature of marginality vary from place to place, depending on the natural resource, livelihood strategy, climatic, agro-ecological, and socio-cultural conditions. Local attributes of marginality were assessed in four different districts of rural Ethiopia. Extreme land degradation was a key force in one district, lack of credit in another, competitive commercial pressure in another district, and resource management practices according to cultural values in the remaining district. There was always a complex interplay of various factors that exclude some people from the benefits of economic growth that others enjoy. Independently from the different features of marginality, this interplay was found to be a root cause of poverty in all of the districts studied.
\end{abstract}

Keywords Ethiopia $\bullet$ Marginality $\bullet$ Poverty $\bullet$ Agro-ecology $\bullet$ Local narratives

\subsection{Introduction}

Poverty is widespread in developing countries like Ethiopia. There are both global initiatives and national poverty reduction programs, like the United Nations' Millennium Development Goals (MDG) and domestic efforts such as the Poverty Reduction Strategy Papers and the Productive Safety Net Programs (Admassie and Abebaw Chap. 17 this volume). The national government, NGOs, and bilateral and multilateral organizations are all making concerted efforts to meet the MDGs and to implement national poverty reduction efforts. However, poverty seems to persist

\footnotetext{
T.W. Gole $(\triangle) \bullet$ F.G. Ilfata $\bullet$ M. Tafa $\bullet$ A. Aregachew

Environment and Coffee Forest Forum (ECFF), Addis Ababa 28513, Ethiopia

e-mail: twgole@ethionet.et
} 
everywhere in Ethiopia. The severity of poverty and the proportions of the poor vary from place to place, depending on various factors. Marginality is often found to be a root cause of poverty (von Braun and Gatzweiler Chap. 1 this volume). Socio-economic development efforts may not equally reach all of the poor because the barriers that marginalize some segments of society prevent policies and development efforts from comprehensively incorporating the poor.

Marginality has different meanings depending on context. In this chapter, we consider marginality as Gatzweiler et al. (2011; see Chap. 2 this volume) define it. This study was conducted as part of a pilot research project on marginality and extreme poverty in Ethiopia led by the Environment and Coffee Forest Forum in Ethiopia. We conducted a field investigation in four communities located in separate districts of the regional state Oromiya with distinct environmental, social, and cultural circumstances. The districts (locally called woredas) are: Jida in North Shoa, Yayu in Ilubabor, Adami-Tullu Jiddo Kombolcha in East Shoa, and Arero in Borana. The case study sites were selected in order to capture some of the diverse aspects of marginality by considering the differences in agro-ecological contexts, livelihood strategies, cultural practices, and natural resource endowments. The objectives of the study were:

- to assess the diverse factors that contribute to marginality and poverty across gradients of agro-ecological and climatic conditions and livelihood strategies in selected parts of Ethiopia

- to better understand the perceptions of poverty among the rural marginalized poor communities

\subsubsection{Agro-ecological Characteristics of the Study Sites}

Jida district—Central Highlands:

- cool humid or semi-humid climate

- highly degraded land, steep slopes, and seasonally flooded plains at the base of slopes

- local livelihoods are primarily based on cereal production and mixed-agricultural systems

- annual precipitation is highly variable $(635-1,350 \mathrm{~mm})$

- mean annual temperature is $15^{\circ} \mathrm{C}$

- the primary sources of livelihood are food crops and livestock production

Yayu district—Southwestern Highlands:

- area is well endowed with natural resources, over $50 \%$ forest cover remaining, fertile soils, and streams and rivers flow throughout the year

- this area is relatively far from major markets

- local livelihoods are primarily based on food crops and coffee production. Coffee alone was the source of around $75 \%$ of the cash income for the study community or kebele (Ethiopia's smallest geopolitical unit) of Wabo near the town of Yayu 
- mean annual precipitation is about $1,850 \mathrm{~mm}$, with annual variation ranging $1,600-2,600 \mathrm{~mm}$

- mean annual temperature is $20^{\circ} \mathrm{C}$

Adami-Tullu Jiddo Kombolcha district_Central Rift Valley:

- arid to semiarid climate with topography ranging from lowlands to mid-altitude highlands

- annual precipitation is between 600 and $800 \mathrm{~mm}$

- mean annual temperature is $20^{\circ} \mathrm{C}$

- area has fertile, young, volcanic soils and extensive surface and groundwater resources

- water for irrigation is available (Lake Ziway and its tributaries)

- livelihoods are primarily based on the production of food crops such as fruit and vegetables supplemented by livestock production

- relatively close proximity to major domestic markets

- this is a major vegetable producing area of the country, both by commercial and small-scale producers (commercial farms also produce flowers for export, and grapes and other fruits for local markets and industries)

Arero district—Southern Lowlands:

- arid climate

- predominantly covered by Acacia spp. woodlands and dry forests that are managed as rangeland for livestock production

- mean annual precipitation is about $600 \mathrm{~mm}$ with a bimodal distribution pattern

- mean annual temperature is $20^{\circ} \mathrm{C}$ (Halake 2010)

- local livelihoods primarily depend on nomadic livestock production, although a minority has adopted cultivating maize on small parcels close to permanent settlements

- rangelands are highly degraded with exposed soils that are nearly devoid of vegetation in most areas

\subsubsection{Methods}

The four districts were systematically selected based on their distinct climatic, physical, and agro-ecological conditions. In each district, consultations were held with administrators and senior agricultural development officers in order to select each case-study community. At the selected study kebeles, discussions were held with local experts and key local informants such as development agents and extension workers to select the specific case study community within each kebele. In the selected communities, group discussions were held with representatives of different demographic groups (youths, women, elders) and community representatives. Interviews with key local informants were held with two or three individual household heads from each of three locally determined relative wealth categories: poor, middle-income, and wealthy households. 
Semi-structured interviews were used to consult administrators, agricultural development officers, extension workers, and development agents at the district and kebele levels. The local farming community consultations were held in two stages, first with a group of key informants and community representatives, and later with individual household heads from each wealth category. Participatory Rural Appraisal (PRA) tools such as group discussions, transect walks, participatory mapping, and wealth-ranking exercises were conducted with the community representatives. At this stage the key local informants defined and characterized the three household wealth categories and identified two or three household heads from each wealth category for further individual discussions. Afterwards, semi-structured interviews were conducted using checklists of discussion points to obtain life history and other household data. Guided walks with the key informants were undertaken to observe local biophysical conditions and the status of natural resources.

\subsection{Findings}

The marginalized poor identified in the study sites included individuals of all ages, although the perceived root causes of poverty differed among social and demographic groups. Perceptions of poverty and wealth also varied by location. The major emphasis of our investigations was to characterize natural resource bases, economic and livelihood conditions, infrastructure, and other legal and human rights related issues that we expected to have an impact on marginality and poverty. The importance of these factors differed among locations and hence emphasis was placed on factors that appeared to be more relevant to specific case study sites.

Jida. This district is located $70 \mathrm{~km}$ northeast of Addis Ababa. Despite its vicinity to the capital city it has suffered from a lack of basic infrastructure like electrical power, telecommunications, and environmental related investments. Climatically the area is classified as temperate and there are three distinct seasons locally known as the Bega (a dry season from October to January), the Belg (a brief rainy season from February to May), and the Kiremt (a longer rainy season from June to September). The greatest amount of annual precipitation occurs during the Kiremt. The major land cover types are cropland and rangeland, with remaining areas covered by forest and scrub. The total human population of the case study kebele in 2007 was 8,329, with nearly equal numbers of male $(4,129)$ and female $(4,200)$ residents (CSA 2007). The local livestock population was approximately 18,310 head, dominated by sheep, followed by cattle, donkeys, horses, goats, and mules.

Jida is a typical example of the highly degraded conditions found in much of the Central Highlands of Ethiopia. Erosion has led to low infiltration capacity and high runoff on upper slopes, resulting in seasonal flooding and gully formation in the valley bottoms. The short rainy season (Belg) is the best season for crop production because the higher rainfall during the Kiremt causes flooding and water-logged soils that damage crops. Some informants mentioned that the Belg rains only come at the 
Table 22.1 Locally determined attributes of wealth in the community of Gango, Jida district, some indicators apply to more than one wealth category, distinctions were made using a combination of indicators

\begin{tabular}{|c|c|c|}
\hline Rich & Middle-income & Poor \\
\hline $\begin{array}{l}\text { Owns a house with a corrugated } \\
\text { steel roof with separate rooms } \\
\text { for family, guests, kitchen, } \\
\text { livestock, and storage } \\
\text { Owns more than two pairs of oxen } \\
\text { Owns more than three head of cattle } \\
\text { Owns more than ten sheep } \\
\text { Food self-sufficient even } \\
\text { in unproductive years } \\
\text { Capable of lending money to others } \\
\text { Owns a horse, mule, or donkey } \\
\text { Capable of sending children to } \\
\text { school up to the secondary-level } \\
\text { (which requires renting a room } \\
\text { in a nearby town) }\end{array}$ & $\begin{array}{l}\text { Owns one or two pairs } \\
\text { of oxen } \\
\text { Owns two head of cattle } \\
\text { Owns around ten sheep } \\
\text { Generally food self } \\
\text { sufficient } \\
\text { Capable of sending } \\
\text { children to school } \\
\text { Capable of going } \\
\text { to health center } \\
\text { without support } \\
\text { Capable of supporting } \\
\text { family for } 1 \text { year in } \\
\text { case of crop failure } \\
\text { Owns a horse, } \\
\text { mule or donkey }\end{array}$ & $\begin{array}{l}\text { Does not own oxen or sheep } \\
\text { Does not own land or provides } \\
\text { land to share croppers } \\
\text { Owns a simple house } \\
\text { with a grass roof } \\
\text { Unable to send children } \\
\text { to school } \\
\text { Unable to provide appropriate } \\
\text { clothing for family } \\
\text { Unable to go to health center } \\
\text { in case of sickness and } \\
\text { at risk of death as a result } \\
\text { of serious illness }\end{array}$ \\
\hline
\end{tabular}

appropriate time and amounts for crop production once every 3 years, leaving the population in a perpetual food deficit for two out of every 3 years. As a coping mechanism most young male household heads migrate to Addis Ababa to work in the construction sector as unskilled day laborers. Elderly people, women, and other residents who are incapable of migratory labor have only one choice to deal with adversity, to take out loans from illegal money lenders.

Livestock production seemed to be a stable livelihood option in the area due to its proximity to Addis Ababa, where there is a very high demand for sheep. The main constraints for livestock production were water shortages during the dry season and disease. Based on their own economic status and perspectives, local participants in the focus group discussion in the community of Gango helped to characterize the local attributes of the three wealth categories (Table 22.1). Local representatives of each of the wealth categories were interviewed to better understand their perceptions of poverty and associated causes.

Mr. Hailu Gurmu was a 72 year-old household head identified as poor. His household had seven members. Mr. Gurmu was frustrated during the study year because his barley crop failed due to meager Belg rainfall. To survive the subsequent food shortage, he needed to either sell one of his sheep or else borrow money at a high interest rate from a rich man in the village. His son had to migrate to Addis Ababa to work as a day laborer. This case revealed that even for households with some assets (land), productivity depends exclusively on environmental/ climatic factors like rainfall. Although Mr. Gurmu was losing hope on the prospects of crop production, he viewed raising sheep as a good livelihood opportunity; however, he did not have the financial resources to buy more sheep. 


\section{Box 22.1 Narrative of Mr. Tadesse Teshome}

Tadesse Teshome was a 69 year-old male household head responsible for a family of eight. Most of his children were married and he lived with his wife and some of his grandchildren. He owned two houses with corrugated steel roofs, one for his family and the other for livestock. There was a third grass thatch roofed house used to shelter horses and as a cooking area. He owned 2.5 ha of land and also cultivated another 2.5 ha as a share cropper. He owned 2 pairs of oxen, 4 head of cattle, 15 sheep, 2 chickens (others had died from disease), 3 donkeys, 2 horses, and a mule. At the time of the interview he was cultivating eucalyptus plantations and was planning to plant more. He sold sheep and sometimes oxen to generate income. When rainfall was good, he sold surplus crops (barley, wheat, beans). He mentioned the erratic nature of rainfall as the major challenge for both crop and livestock production in the kebele. He credited hard work as a reason for his success. As a well-off person in the village, he claimed to support other people by providing interest-free loans (a matter later disputed by poor local residents who claimed to have taken out loans from him with interest) although he admitted that loan recipients sometimes provided labor. He saved money through Iqub. When asked what he did with his money, he mentioned that he had bought a grinding mill. He also mentioned that he used to be a tailor and that his business had been inherited by his son. Mr. Teshome was planning to purchase another grinding mill in the near future.

Mrs. Ilfe Badho was a 55 year-old female household head identified as belonging to the middle-income category. In addition to agriculture she diversified her sources of income by preparing drinks and selling them locally, and was able to save money through local institutions such as Iqub. She also took advantage of access to micro-finance loans. Mrs. Badho claimed that her self-motivation, hardworking nature, and support from her children also contributed to her economic status.

Mr. Tadesse Teshome belongs to the rich local wealth category. Income diversification was one of the primary reasons for his economic success. He receives income from share cropping, livestock husbandry, a grain grinding mill, moneylending to poor households, tree plantations, and a home garden. Details from the interview with Mr. Teshome are summarized in Box 22.1.

Yayu. This district is located in the Illubabor Zone of the regional state of Oromiya, approximately $550 \mathrm{~km}$ west of Addis Ababa on the major highway to Metu. The district is composed of 18 kebeles, of which 17 are rural and one is urban. Five landcover types were observed in the district, which was dominated by forest and agricultural crops, and included smaller areas of rangelands, wetlands, and settlements. 
Yayu district has the highest percentage of forest cover in Ethiopia. Most forested areas and the surrounding landscape are managed as the UNESCO (2010) designated "Yayu Coffee Forest Biosphere Reserve." The local communities depend heavily on the forest, mainly for coffee, spices, and honey. The main local food crops were maize, sorghum, and teff. Coffee was the major cash crop in the area (although it is also consumed locally), followed by chat, which is a leaf chewed as a stimulant by many people in urban areas (Gole 2003; Gole et al. 2009; Fite 2008). According to the most recent census data available the human population of the district was 52,829, of which 26,720 were male and 26,109 were female (CSA 2007). There were 9,917 households, out of which 1,348 were female-headed. Around 4,103 (41\%) of the household heads were unemployed at the time of our interviews.

The district is characterized by the high amount of forest cover, high rainfall, high suitability for coffee and honey production, and considerable potential for the production of food crops like maize, sorghum, teff, and others. Local communities considered the undulating terrain, soil erosion, and low productivity as major challenges to crop agriculture. Many areas have steep slopes and require soil conservation measures to avoid degradation and severe soil erosion. Most high slope areas, however, are forests managed for coffee production with minimal risk of erosion. For croplands on slopes, NGOs like Menschen für Menschen, Ethio-Wetlands, and the Natural Resources Association have introduced "bund" terraces that are planted with vetiver grass to prevent erosion.

The area is accessible via a highway that connects Addis Ababa to Metu, Gambella, and South Sudan. However, the local road network connecting the kebele to the highway and local towns was not well developed. Given the steep slopes and difficult terrain, transporting products to markets was a major challenge in the area. Telecommunications infrastructure and access to electricity, clean water, and health services were at rudimentary stages of development. Most farmers find it difficult to transport their harvests (especially coffee) to market during the rainy season. As a result, a few wealthy merchants from local towns built warehouses in rural areas where they purchase coffee at low prices directly from producers and store the product until they can sell it for a higher price. Poor farmers who cannot process their own product or keep their product until the dry season (when prices are better) have no choice but to sell their coffee at very low prices. There are few secondary schools and health centers accessible to most rural residents, in some kebeles people must walk up to 3 or $4 \mathrm{~h}$ in order to reach the closest health centers.

Coffee production was the major source of income (over $70 \%$ ) for most households in Yayu. Honey and spices were other important sources of income. Recently some households also started growing fruits, vegetables, and chat. Most of these livelihood options were linked to the ownership or access to land. In the absence of land markets, the typical size of inherited land parcels has gotten smaller over time due to population growth. As a result, harvest yields (especially of food crops) were getting smaller and in many cases could no longer support household consumption, making most small-producers reliant on food purchased from markets. 
Coffee prices are influenced by the global market and vary considerably. The productivity of coffee plantations depends on the intensity of management, which requires labor that the poor may not be able to afford or provide, thereby reducing available income. This situation prevented most households from being able to support their family year-round based on coffee income, making it necessary to find other sources of income. Some farmers also worked as day laborers on larger coffee plantations or in nearby towns. Elderly and female landowners often had to offer their land to others for share cropping. In the case of shortages of food and other consumables for the family, households occasionally have to borrow money from local lenders at high interest rates.

Share cropping is a common practice in many parts of rural Ethiopia. It is an option for households that own land but cannot afford the production inputs such as oxen for plowing or the required labor. In such cases landowners look for a share cropper who can provide the inputs and labor required to cultivate the land in return for half of the harvest. This is an attractive opportunity, especially for households headed by women or elderly people who cannot manage farmland themselves. In the case of crop production, the share cropper provides seed, fertilizer, labor, and oxen for plowing. In the case of coffee production the share cropper employs labor for weeding (which is carried out at least three times per year) and harvesting.

A problem with share cropping is the lack of regulatory oversight or legal mechanisms for ensuring compliance with agreements made between land owners and share croppers. As a result, the share croppers sometimes refuse to provide the appropriate harvest share to the land owner or else find ways to claim legal rights to the use of the land under false pretenses without the assent of the owner. During the community consultations respondents mentioned that there were many households that had lost their land in this way and afterwards remained landless.

In the Yayu district the poor often receive money from the rich under an agreement to repay the debt with coffee. Agreements are often made when coffee prices are very low (mainly in the rainy season), with loan payments fixed at the current price of coffee. Payments are then made later in the year, when the coffee prices increase (reaching double or over three times the price when loan agreements were made). Such contracts reduce the earning capacity of small-producers, helping to keep them in a state of poverty (Table 22.2).

One of the poor household heads identified by the community and interviewed was Mrs. Alemi Kumsa, a single woman over 60 years of age who lived alone. She owned a 0.5 ha coffee plantation that she contracted to share croppers and 0.5 ha of cropland, which was rarely cultivated due to lack of labor. She claimed that share croppers often cheated her and rarely provided the proper harvest shares. The tragic loss of her husband and sons significantly impacted her life. Share cropping agreements were made through the mediation of brokers with no legal backgrounds. Due to illiteracy, people like Ms. Kumsa are not able to verify the terms of written agreements and are required to believe what they are told by mediators, which in some cases is not consistent with the signed agreement. 
Table 22.2 Locally determined attributes of wealth in the kebele of Wabo, Yayu district

\begin{tabular}{|c|c|c|}
\hline Rich & Middle-income & Poor \\
\hline $\begin{array}{l}\text { Owns a house with a } \\
\text { corrugated steel roof and } \\
\text { full furnishings, including } \\
\text { a sofa, TV, and shelf } \\
\text { Owns more than } \\
\text { one pair oxen } \\
\text { Owns more than } 1 \text { ha } \\
\text { of well-managed } \\
\text { coffee plantation } \\
\text { Owns more than } 0.5 \text { ha } \\
\text { of cropland } \\
\text { Food self sufficient } \\
\text { Capable of sending } \\
\text { children to school } \\
\text { Capable of providing decent } \\
\text { clothing for family } \\
\text { Capable of storing maize } \\
\text { Capable of supporting family } \\
\text { for more than a year in } \\
\text { case of production failure } \\
\text { Owns one donkey } \\
\text { Owns more than five sheep } \\
\text { Owns more than five goats }\end{array}$ & $\begin{array}{l}\text { Owns a house with either } \\
\text { a corrugated steel or } \\
\text { grass thatch roof } \\
\text { Owns } 0.5-1.0 \text { ha of } \\
\text { coffee plantation with } \\
\text { moderate management } \\
\text { Owns } 0.5 \text { ha of cropland } \\
\text { Owns a single ox } \\
\text { Co-owner of a cow } \\
\text { (shared among } \\
\text { households) } \\
\text { Owns two or three sheep } \\
\text { Food self sufficient } \\
\text { Unable to withstand poor } \\
\text { growing conditions } \\
\text { Capable of sending } \\
\text { children to school } \\
\text { May own a television } \\
\text { set and sofa }\end{array}$ & $\begin{array}{l}\text { Cannot provide adequate food } \\
\text { for family } \\
\text { Works as day laborer or sells } \\
\text { fuel wood for income } \\
\text { May own a coffee plantation } \\
\text { but must allow another person } \\
\text { as share cropper or in exchange } \\
\text { for loan and may work } \\
\text { on own land as laborer } \\
\text { If they possess a coffee plantation, } \\
\text { it is less productive because } \\
\text { of poor management } \\
\text { Unable to send children to school, } \\
\text { who must either live with } \\
\text { others or work } \\
\text { Does not own livestock of any type } \\
\text { Depends completely on labor } \\
\text { for income } \\
\text { Needs support for minor health } \\
\text { services }\end{array}$ \\
\hline
\end{tabular}

In contrast to Alemi Kumsa's situation, middle-income household head Sukare Firisa's (Box 22.2) educational status enabled her to avoid similar problems. Her children were highly educated, which seemed to have contributed to her ability to defend her rights with respect to her share of harvests from sharecroppers and the ability to manage her own coffee plantation. Apart from her education, she was relatively young and healthy and therefore had the physical strength to work. She also earned income by brewing drinks that she sold locally. She did not have savings of any type, which might have enabled her to improve her economic status.

Similar to the other sites, diversification of livelihood means was common among households identified as belonging to the rich wealth category in the community of Wabo. Mr. Fikadu Hailu, a Wabo household head belonging to the rich category, was engaged in coffee, food crops, chat, and sugarcane production. He also owned eucalyptus plantations. Some households identified as rich in this area had also expanded into providing specialized services and opening consumable goods shops.

Adami-Tullu Jiddo Kombolcha. This district is in the East Shoa Zone of Oromiya and had a total population of 142,861 at the most recent census (CSA 2007). The case study was conducted in the kebele of Bochessa, which is located $6 \mathrm{~km}$ east of the town of Ziway. Bochessa had a total of 480 households and 2,855 people. The area is well endowed with natural resources. It has fertile, relatively young, volcanic ash soils and abundant surface and groundwater resources. The area is suitable for 


\section{Box 22.2 Narrative of Ms. Sukare Firisa}

Sukare Firisa is a female household head identified as belonging to the middle-income wealth category. She was 45 years old and had five children, only three of which lived in her home, which had a corrugated steel roof. The house had three rooms for the kitchen, a bedroom, and a salon furnished with a sofa, television set, and a shelf. Two of her children lived with her ex-husband. Her son was a university student and her daughter had graduated with a nursing degree and was looking for a job. Ms. Firisa was a ninth grade dropout and reliant on agriculture for her livelihood. She owned a 0.75 ha coffee plantation and 0.4 ha of cropland. She also owned a shared ox, a cow, three calves, and shared a fourth calf. She provided her cropland to share croppers due to her inability to cover labor and input costs, for which she obtained $600 \mathrm{~kg}$ of maize each harvest. With part of the maize harvest she prepared a local alcoholic drink called arak that she sold locally. Income from ara $k$ sales enabled her to buy teff to add to the remaining maize for the household food supply. She would have inherited a larger coffee plantation, but her late step-mother made a share-cropping agreement on part of the land to someone who later claimed it after the death of the step-mother. Firisa was capable of defending her rights with respect to the share croppers. She managed the coffee plantation by herself. When coffee income declines, she increases arak production and sales. She did not participate in the Iqub saving system or save by other means. She claimed that her reluctance to save stemmed from her mistrust in others, based on prior experiences with people who did not return money she had given them.

all kinds of agriculture using irrigation, including high-value fruits and vegetables, oil seeds, flowers, other food crops, and livestock production. This has attracted considerable investment in floriculture, large and small-scale irrigated agriculture, agro-industries, and recreation. The most fertile and accessible areas were allocated to such investments, reducing the availability of irrigable land for the local community and causing high rates of landlessness.

Rain-fed agriculture is not promising in the area due to the relatively low amount of rainfall. Therefore access to irrigable land was the most critical factor determining the wealth status of households in the area. The soils in the area have salinity problems, which further reduce productivity. The interplay of these three factors (low land ownership, erratic rainfall, and saline soils) greatly diminishes production, leading to a widespread lack of household self-sufficiency in food production.

The district is relatively well developed compared to other parts of Ethiopia. The major highway connecting Addis Ababa to the southern part of the country and Kenya crosses the district and good feeder roads connect the kebeles to major towns and the highway. Schools, mobile phone services, clinics, and health posts are available in most areas. All towns and major rural settlements have electricity. 
Table 22.3 Locally determined attributes of wealth in the kebele of Bochessa, Adami-Tullu Jiddo Kombolcha district

\begin{tabular}{|c|c|c|}
\hline Rich & Middle-income & Poor \\
\hline $\begin{array}{l}\text { Owns more than } 5 \text { ha of fertile } \\
\text { land out of which at least } 2 \text { ha } \\
\text { are irrigable } \\
\text { Owns more than four pair of oxen } \\
\text { Owns a good house, with a } \\
\text { corrugated steel roof } \\
\text { Produces sufficient yield to secure } \\
\text { household nutrition needs } \\
\text { Capable of providing loans and } \\
\text { accessing credit } \\
\text { Capable of sending children to } \\
\text { school } \\
\text { Physically capable of working } \\
\text { Large family labor force to work } \\
\text { on farm } \\
\text { Household heads' ideas/opinions } \\
\text { are accepted by many and } \\
\text { well respected by most } \\
\text { community members }\end{array}$ & $\begin{array}{l}\text { Owns } 4-5 \text { ha of fertile land of } \\
\text { which a minimum of } 1 \text { ha is } \\
\text { irrigable } \\
\text { Owns } 2-3 \text { pairs of oxen } \\
\text { Owns } 10-15 \text { head of cattle and } \\
8-10 \text { goats } \\
\text { Four or more family members } \\
\text { capable of working on farm } \\
\text { Sufficient financial resources or } \\
\text { access to credit to buy } \\
\text { agricultural inputs to boost } \\
\text { yields } \\
\text { Recipients of government } \\
\text { agricultural extension } \\
\text { services, input supplies, and } \\
\text { asset protection during poor } \\
\text { harvests } \\
\text { Capable of storing sufficient seed } \\
\text { for planting next crop and } \\
\text { enough pasture for livestock }\end{array}$ & $\begin{array}{l}\text { Lack grain storage } \\
\text { capacity near home } \\
\text { Owns almost no land } \\
\text { except home/garden } \\
\text { plot } \\
\text { Does not own oxen and } \\
\text { other livestock } \\
\text { Owns few home utensils } \\
\text { Is in poor health } \\
\text { Physically incapable of } \\
\text { work on farm or as } \\
\text { day laborer }\end{array}$ \\
\hline
\end{tabular}

Transportation is not a problem in the area due to the good road networks and common use of carts in both rural and urban areas. The town of Ziway is the commercial center of the area, connecting the larger markets in Addis Ababa, Adama, Shashamanne, and Hawassa.

Mixed agriculture (crop and livestock production) is the major livelihood activity in the area. The major staple food crops produced in the kebele are maize, teff, wheat, and barley. Local farmers also produced Haricot bean, tomato, and onion as cash crops. The typical size of land holdings per household range from 0.75 to 3.0 ha. About $46 \%$ of the rural population is landless, $27 \%$ owned 1-2 ha, and $22 \%$ owned less than 1 ha. Share cropping and land leasing for periods of up to a few years are common practices in the area, by both local subsistence farmers and commercial producers from urban areas.

With increased urbanization and commercial agriculture around Lake Ziway, employment as day laborers and petty tradesmen is increasingly becoming an alternative or complementary source of income for local residents. Other livelihood sources included fishing, livestock production, livestock finishing (pre-slaughter), and poultry production. The results of the local wealth ranking exercise in Bochessa are presented in Table 22.3.

As the representative head of a poor household, Mr. Wario Dinko, a 60 year-old, physically disabled man with a family of three owned 0.75 ha of non-irrigated land. He did not own oxen, but did own three chickens. Because of his inferior economic status, Mr. Wario felt marginalized. He believed that the voices of the poor like himself are not heard or are not taken seriously by the community, and that their 


\section{Box 22.3 Narrative of Mr. Kumbi Ababa Tufa}

Kumbi Ababa Tufa was an illiterate 65 year-old man and the head of a family of 11 . He was able to send all of his children to school at the appropriate age. He owned 1.5 ha cropland (of which 1 ha was irrigated), 2 oxen, 2 dairy cows and 4 other cattle, 2 sheep, and 2 donkeys. In addition, Mr. Tufa had one house in the town of Batu where he rented three rooms and earned 500 birr (US\$30) per month. In his home he had a television set and a tape recorder. He also had a bicycle for transportation and a motorized pump for irrigation. In 2010-2011 he harvested 4,000 kg of maize and $100 \mathrm{~kg}$ of teff. He attributed his success to hard work. He earned enough money to pay for most of his assets from fishing on Lake Ziway for many years. He was convinced that hard work and saving money can change the life of any person.

problems are not known to development agencies or policy makers. From his perspective, many policies and development activities fail to include the priorities of the marginalized poor. Similar poor households encountered in the area had very little land, none of which was irrigable. Groundwater is available but requires investment to access, which poor households could not afford. Most poor households are unable to support their families and depend on direct government aid through social safety-net programs.

On the other side of the spectrum, Mr. Kumbi Ababa Tufa was identified as a rich household head in the community (Box 22.3). The amount of land owned by Mr. Tufa was not much more than typical members of the middle-income category. However, he managed the land on his own, was able to irrigate, and produced high-value vegetables. In addition, his life story demonstrates the potential of fishing as a livelihood option that landless farmers could take advantage of.

Arero. This district is located in the Borana Zone of Oromiya, the district capital Mata Gafarsa is located $675 \mathrm{~km}$ south of Addis Ababa. The district has a total area of 957,639 ha, of which only $5 \%$ is cultivated land. The greatest land cover in the area was rangeland, followed by a lesser amount of forest and settlements. There are 21 kebeles in the district, of which 20 are rural and one is urban. The case study kebele, Alona, is a rural kebele with the same land cover pattern that is typical for the whole district. Rainfall during both rainy seasons is erratic. In 2010-2011 there was no rain at all during the shorter rainy season. The district is an important watershed of the Dawa River, one of the major tributaries of the Juba River in Somalia. The total population of Arero district was estimated to be 73,500 in 2007 (CSA 2007). The number of households in the district was 12,487, of which 6,722 (53.8\%) were female-headed. In Alona female-headed households constituted only $36 \%$ of the total. The principal reasons for the exceptionally high percentage of female-headed households in the district were polygamy and a high divorce rate, and violent conflict among ethnic groups. About $95 \%$ of the 
rural population belonged to the Oromo ethnic group, others included Somali, Konso, Gari, Burji, and other ethnicities.

Natural resources in Arero include high altitude dry forests, lowland woodlands, diverse and unique species of wild animals and mineral resources. Dry Afro-montane forests cover highland areas above $1,500 \mathrm{~m}$. The lowland woodlands were rich in various useful species of acacia, gums, and incense-bearing species. The district is rich in mineral resources like gold, platinum, tantalum, and precious stones. Most of the natural resources are not being exploited by local communities.

The communities in the area are predominantly pastoralists and the major economic activity is livestock production. Over time the pastoralists of this area have developed unique breeds of cattle, camel, goat, and sheep. The local Borana livestock breeds are known in Ethiopia for the quality of their dairy and meat, which are also exported. Livestock resources are threatened by frequent drought, shortages of animal feed, and the encroachment of invasive woody plants on pasture lands.

The road connecting the district to major administrative towns and markets is in very poor condition, making traveling and transporting goods in the area very difficult. Most rural villages are not connected to the road network and residents had difficulty accessing health care services and markets. The major local commercial center is the town Mata Gafarsa. The nearest livestock markets are in the Yabello and Mega districts that require 2 or 3 days to reach on foot. Telecommunications, drinking water distribution, and electricity infrastructure were not available in the area. The district residents fetch water from rivers or streams during the rainy season and from springs, deep wells, ponds, and even from areas as far as $100 \mathrm{~km}$ away like the town of Yabello during the dry season. Generally, water was a scarce resource in this district.

On the other hand, human and veterinary health posts and schools are available in many kebeles, including the case study site. There were also three health centers in the district. Yet, the health posts, clinics, and health centers lacked qualified staff and medical supplies to provide their intended services. For proper medical services, people had to travel over $100 \mathrm{~km}$ to reach Yabello. There was one lower primary school (1-4th grade) in each kebele, and upper primary schools (1-8th grade) in some kebeles. Alona had schools of both kinds.

Livestock production contributed over $90 \%$ of the total household income. In the entire district there were 157,000 cattle, 58,462 sheep, 80,252 goats, 35,165 camels, 18 horses, 1,403 mules, 5,742 donkeys and 11,980 chickens (CSA 2007). In Alona there were about 11,754 head of cattle, 4,900 sheep, 5,220 goats, 4,251 camels, 98 mules, 314 donkeys, and 135 chickens. The major constraints on livestock production are drought, feed shortages, diseases, and market access. In spite of all the problems livestock population has grown beyond the carrying capacity of the area, leading to land degradation and deterioration of critical resources like pasture and water.

Some households supplement income through crop production (maize), trade, mining, and employment as day laborers, especially among the poor. According to Boku (2008), $75 \%$ of the households that engaged in crop cultivation belonged to 
Table 22.4 Locally determined attributes of wealth in the kebele of Alona, Arero district, counting the total number of cattle is culturally taboo in the Borana communities, where only the number of dairy cows is counted

\begin{tabular}{|c|c|c|}
\hline Rich & Middle-income & Poor \\
\hline $\begin{array}{l}\text { Owns a house with a corrugated } \\
\text { steel roof in town }\end{array}$ & \multirow{2}{*}{$\begin{array}{l}\text { May or may not own a } \\
\text { house with a corrugated } \\
\text { steel roof in town }\end{array}$} & $\begin{array}{l}\text { Owns one small house with a } \\
\text { grass roof in a rural village }\end{array}$ \\
\hline Food self-sufficient & & Not food self-sufficient \\
\hline Owns more than 50 dairy cows & Food self-sufficient & \multirow{4}{*}{$\begin{array}{l}\text { Owns 5-30 dairy cows } \\
\text { (someone who does } \\
\text { not own cows is referred } \\
\text { to as "Qollee," meaning } \\
\text { absolutely or extremely }\end{array}$} \\
\hline Capable of sending children to & Owns 30-50 dairy cows & \\
\hline school and covering all costs & Capable of sending & \\
\hline $\begin{array}{l}\text { Capable of saving money at credit } \\
\text { and saving institutions }\end{array}$ & $\begin{array}{l}\text { children to school } \\
\text { covering some costs }\end{array}$ & \\
\hline Able to cover health care costs & \multirow{3}{*}{$\begin{array}{l}\text { Capable of saving } \\
\text { to some extent, } \\
\text { and also of helping } \\
\text { other households that } \\
\text { suffer shocks or deaths }\end{array}$} & poor) \\
\hline $\begin{array}{l}\text { Owns a mix of livestock } \\
\text { (cattle, oxen, goats, sheep. }\end{array}$ & & $\begin{array}{l}\text { Unable to send children } \\
\text { to school }\end{array}$ \\
\hline $\begin{array}{l}\text { camels, donkeys, horses, } \\
\text { and mules) }\end{array}$ & & $\begin{array}{l}\text { Unable to save money, either } \\
\text { assisted by clan or aid }\end{array}$ \\
\hline \multirow{5}{*}{$\begin{array}{l}\text { Capable of helping poor } \\
\text { neighbors and other } \\
\text { households in all aspects } \\
\text { (providing money, milk, } \\
\text { materials, and grain) in case } \\
\text { of funeral or food shortages }\end{array}$} & Owns a mix of livestock & May own a mix of livestock \\
\hline & (cattle, oxen, goats, & \multirow{4}{*}{$\begin{array}{l}\text { Dependent on support } \\
\text { of others, aid, or work } \\
\text { as a day laborer }\end{array}$} \\
\hline & mels, and & \\
\hline & & \\
\hline & $\begin{array}{l}\text { Self-sufficient in every } \\
\text { aspect }\end{array}$ & \\
\hline
\end{tabular}

the customary economic category of "self-reliant." Trade mainly involved livestock, livestock products, consumable goods, and grain. Small-scale mining of gold and other minerals by otherwise unemployed youths also occurs locally, a livelihood that is being learned from immigrant miners. There is significant variability in the wealth status among community members. A traditional local indicator of wealth is the number of livestock. A few individuals had large herds of cattle, but the majority of local residents had few or none.

The stories of some of the poor households illustrate how drought has the ability to impoverish people in Borana. In 2010-2011, many households lost all of their livestock due to 10 months of drought. It was evident from the stories of the "rich" and "middle-income" category household heads that income diversification helped them cope with vulnerability in a marginal environment. In addition to traditional livelihoods based on livestock production, the creation of alternative businesses or employment opportunities could contribute to poverty reduction.

Aside from the naturally marginal environmental conditions, culture also played an important role in asset accumulation of individuals in Borana. The strong cultural value attached to livestock ownership and the reluctance to sell livestock when the animals are in good condition during the season when prices are highest was the main barrier to reducing herds to more sustainable levels. Food shortages for people coincided with the dry season, when there were also feed and water shortages for livestock. This means that the physical condition of livestock suffers during the dry season, reducing their market value (Table 22.4). 


\section{Box 22.4 Narrative of Mr. Doyo Guyo}

Doyo Guyo was an 85 year-old man with 17 children from 3 wives, of which 11 were married, and 6 were living with the family. At the time of the interview he was the head of a household of ten living in a multipleroom house. He was also the head of his community. Mr. Guyo owned more than 50 dairy cows, 21 goats, 10 sheep, a donkey, 10 chickens, and a mule. In addition Mr. Guyo owned a home with a corrugated steel roof in Alona and 0.5 ha of cropland for maize production. He harvested around $1,000 \mathrm{~kg}$ of grain for food and the cornstalks served as animal feed. The household did not produce enough food for the family and Mr. Guyo augmented his income by selling livestock. He was not receiving any aid from the government or NGOs. He had lost his parents and all of his livestock to a drought long time ago and afterwards had to take care of his brothers and sisters. He claimed to have earned his assets through hard work. Most of his cattle were taken by members of the Guji and Garba clans during a conflict in 1992. At that point he received support from his clan through the traditional Buusaa-Gonofaa mutual support system of the Borana Oromo. He also earned additional income working as a day laborer, selling fuel wood, and locally trading tobacco, cattle, and consumable goods. He was not saving money since there was no culture of saving like the Iqub in the area. He started cultivating land to reduce his dependency on livestock. As a future strategy, he planned to cultivate more land for subsistence using improved agricultural techniques to increase production, to reduce the number of livestock he owned, to open a savings account at a bank, to purchase a house with a corrugated steel roof in Yabello, to harvest and store hay for the dry season, and to seek other means to diversify his income.

The entrenched cultural practice in Borana of providing help to the poor by rich individuals, as well as a collective self-help system called "Buusa-Gonofaa" are excellent concepts for reducing abject poverty. In most of the areas studied in Ethiopia, the "rich" community members sometimes took advantage of (and were partly responsible for) the poverty of others. In Borana, however, the wealthier families help the poor without charging interest or seeking other economic gain. Similarly, social-oriented businesses could help the poor to build assets based on locally available resources and opportunities. The story of Mr. Guyo (Box 22.4) provides evidence of how the community-based coping systems like Buusaa-Gonofaa and individual efforts help residents recover from natural and human-induced shocks. 


\subsection{Conclusion}

We found that poverty continues to be widespread in Ethiopia, even in areas endowed with a broad range of natural resources and where the cultivation of cash crops is possible. The extent of poverty and the causes and nature of marginality of the poor vary from place to place, depending on the resource base, livelihood strategies, and the climatic, agro-ecological, and socio-cultural conditions. In the Jida district in the central highlands, extreme land degradation on slopes, erratic rainfall, and unsustainable forestry practices on the valley plains have contributed to the marginality of local households. Environmental degradation was often partially caused by over-exploitation of resources. As a consequence, people suffer from frequent crop failures, poverty, and hunger. Exploitation of the poor by wealthier individuals through money lending at high interest rates worsens the situation of many of the poor. As a result, they need to migrate seasonally to urban areas in search of employment opportunities. Marginalization here seems to be predominantly caused by anthropogenic environmental factors.

Contrary to Jida, the Yayu district is endowed with plentiful natural resources. The region offers immense agricultural potential, which has attracted immigrants from other parts of the country. The lack of formal credit facilities, the practice of providing high-interest personal loans, shortages of family labor, and the limited size of coffee plantations all contributed to the poverty of some community members. In addition, the lack of regulatory institutions for enforcing compliance with share cropping agreements exposed the poor and elderly to exploitation. Thus, marginalization here seemed to be mainly rooted in institutional factors.

In the Adami Tullu Jiddo Kombolcha district the potential for income generation depends on the possession of land with potential for irrigated agriculture and livestock production. The proximity of the district to major domestic markets has attracted investment in commercial agriculture, displacing local residents and leaving them with only marginal production areas. The proportion of landless households in the district is very high compared to other rural areas in Ethiopia. Here, economic factors in the form of agricultural investments and related factors such as access to irrigation water are the main causes for marginality.

On the other hand, degraded rangeland and water resources, cultural values attached to livestock, poor range management and livestock production practices, and marginal environmental conditions were all factors contributing to poverty in the pastoralist community of Borana. Although drought is a natural calamity, the high social value given to cattle has inhibited the practice of accumulating financial savings, which would help households cope with adverse conditions during seasonal droughts and reduce pressure on grazing areas and surface water resources. The traditional self-help community institution of Buusaa-Gonofa among the Borana pastoralists was an important coping mechanism for incidences of drought and human-induced disasters. As a result, ecological and spatial factors are the main causes for marginality experienced by people in this area. 
Open Access This chapter is distributed under the terms of the Creative Commons Attribution Noncommercial License, which permits any noncommercial use, distribution, and reproduction in any medium, provided the original author(s) and source are credited.

\section{References}

Boku TD (2008) Pastoralism under stress: resources, institutions and poverty among the Borana Oromo in Southern Ethiopia. Dissertation, Norwegian University of Life Sciences, Aas

CSA (2007) Summary and statistical report of the 2007 population and housing census results. Central Statistical Agency of Ethiopia, Addis Ababa. http://www.csa.gov.et/pdf/Cen2007_ prelimineray.pdf. Accessed 20 Sept 2012

Fite GI (2008) Remote sensing and GIS assisted participatory biosphere reserve zoning for wild coffee conservation; case of Yayu forest. Thesis, Addis Ababa University, Addis Ababa

Gatzweiler F, Baumüller H, von Braun J, Ladenburger C (2011) Marginality: addressing the root causes of extreme poverty. ZEF working paper no. 77, Center for Development Research, University of Bonn, Bonn

Gole TW (2003) Vegetation of the Yayu forest in SW Ethiopia: impacts of human use and implications for in situ conservation of wild Coffea arabica L. populations. Cuvillier Verlag, Göttingen

Gole TW, Feyera S, Kassahun T, Fite G (2009) Yayu coffee forest biosphere reserve nomination form. Ethiopian MAB National Committee, Addis Ababa

Halake D (2010) The impacts of development interventions on customary institutions of forest resource management among the Borana Oromo Of southern Ethiopia. Thesis, Addis Ababa University, Addis Ababa

UNESCO (2010) World Network of Biosphere Reserves 2010: sites for sustainable development. United Nations Education, Science, and Cultural Organization, Paris 